\title{
Evaluation of Stomach Tubes and Gastric Lavage for Sampling Diets from Blue Catfish and Flathead Catfish
}

\author{
D. Scott Waters, * Thomas J. Kwak, Joshua B. Arnott, \\ and William E. Pine III ${ }^{1}$ \\ U.S. Geological Survey, North Carolina Cooperative Fish and Wildlife Research Unit, ${ }^{2}$ \\ Box 7617, North Carolina State University, Raleigh, North Carolina 27695-7617, USA
}

\begin{abstract}
We compared the ability to extract all stomach contents by using stomach tubes or gastric lavage to sample diets from blue catfish Ictalurus furcatus and flathead catfish Pylodictis olivaris. Pulsed gastric lavage (PGL) removed a significantly greater proportion of stomach content mass $(95.6 \%)$ from blue catfish than did stomach tubes $(14.6 \%)$. Percent mass of flathead catfish contents removed with PGL (96.0\%) was not significantly different from that removed with stomach tubes $(86.9 \%)$. Based on the greater effectiveness of PGL for blue catfish, combined with a shorter mean time required per sample (69 versus $118 \mathrm{~s}$ ) and the better preservation of extracted diet material, we recommend using PGL as a nonlethal technique to collect diet samples from large catfishes.
\end{abstract}

Diet analysis, an important component of fish research or management investigations, is most often accomplished through the inspection of stomach or foregut contents. Killing fish to excise the stomach or digestive tract may be undesirable in some cases because of potential population impacts or public perceptions (Seaburg 1957; Crossman and Hamilton 1978; Light et al. 1983; Hartleb and Moring 1995). Faced with this restriction, fisheries scientists may require effective, nondestructive, live-release methods for collecting stomach contents. Two commonly used nonlethal techniques are stomach tubes and pulsed gastric lavage (PGL); their effectiveness (ability to extract all stomach contacts) should be assessed before application in scientific studies.

Stomach tubes are clear, smooth tubes (acrylic or glass) of various diameters with ends beveled to ease entry into the stomach to remove contents. Stomach tubes have been used successfully to collect diet samples of brook trout Salvelinus fontin-

\footnotetext{
* Corresponding author: scott_waters@ncsu.edu

${ }^{1}$ Present address: Mote Marine Laboratory, 1600 Ken Thompson Parkway, Sarasota, Florida 34236, USA.

2 The Unit is jointly supported by North Carolina State University, North Carolina Wildlife Resources Commission, U.S. Geological Survey, and Wildlife Management Institute.
}

Received September 26, 2002; accepted March 5, 2003 alis (White 1930) and black bass Micropterus species (Van Den Avyle and Roussel 1980). Although stomach tubes are a simple and effective procedure for most species, their effectiveness on some species may be limited by morphological characteristics such as stomach shape and mouth size and by food particle size (Van Den Avyle and Roussel 1980; Kamler and Pope 2001).

The PGL procedure uses pulses of water to flush the stomach contents from a fish (Seaburg 1957; Foster 1977; Crossman and Hamilton 1978; Light et al. 1983; Hartleb and Moring 1995). Fundamental to the process is the method of delivering water pulses; hand pumps (Seaburg 1957), compression pumps (Foster 1977; Light et al. 1983; Hartleb and Moring 1995), and electrical pumps (Crossman and Hamilton 1978) have been used for this. A tube attached to the pump delivers water to the stomach cavity. In devices using a compression or electrical pump, a means for controlling water flow is also fitted in series with the tubing. Hartleb and Moring (1995) found this technique to be $100 \%$ effective at removing prey items in largemouth bass $M$. salmoides, yellow perch Perca flavescens, pumpkinseed Lepomis gibbosus, and white perch Morone americana, but only $75 \%$ effective for brown bullheads Ameiurus nebulosus, and ineffective for chain pickerel Esox niger.

Our goal was to determine whether stomach tubes and PGL were equally effective for sampling stomach contents of two large catfish species, blue catfish Ictalurus furcatus and flathead catfish Pylodictis olivaris. The effectiveness of both procedures has been evaluated for other species, but not for these fishes. Given the increased interest and advances in catfish angling, management, and research (Irwin et al. 1999; Michaletz and Dillard 1999; Arterburn et al. 2002) and widespread introductions of blue catfish and flathead catfish outside their native ranges (Fuller et al. 1999), this evaluation is needed to ensure that the diet of these species is accurately represented.

\section{Methods}

We collected 63 blue catfish and 95 flathead catfish by boat-mounted, pulsed-DC electrofishing. 
All blue catfish and 12 flathead catfish were obtained from two reaches of the Pee Dee River during May 2001; one reach was downstream of Blewett Falls Dam near Rockingham, North Carolina, and the other was downstream of Tillery Dam near Cheraw, South Carolina. An additional 49 flathead catfish were collected from Sutton Lake in southeastern North Carolina during September 2001, and 35 flathead catfish were collected from the Neuse River near Kinston, North Carolina, during September-October 2001.

After capture, fish were anesthetized in an aerated live well by the addition of a solution consisting of $10 \%$ clove oil, $40 \%$ ethanol, and $50 \%$ distilled water. Once anesthetized (as evidenced by a complete loss of equilibrium), individual fish were removed from the holding tank in no particular order; total length $( \pm 1 \mathrm{~mm})$ and weight $( \pm 1$ g) were measured; and then a diet-sampling technique was assigned for groups of five fish, the first group being assigned randomly. The duration of time required to perform the diet-sampling procedure was recorded for a subsample of the blue catfish studied ( $N=20$ PGL, $N=26$ tube). Stomach content samples collected from each live fish were frozen separately in individual plastic bags, sealed, and labeled. After the diet-sampling procedure, the fish were killed in an overdose solution of the anesthetic described above. Stomachs of each fish killed were excised and frozen separately in plastic bags, sealed, and labeled.

The PGL device constructed for this study, based on the design described by Crossman and Hamilton (1978), consisted of a 12-V bilge pump $(1,382 \mathrm{~L} / \mathrm{h})$ mounted to a Plexiglas frame suspended over the side of the boat. A 1.2-m length of 19.0-mm inside diameter (ID) polyethylene tubing connected the pump to a garden-type, pistolgrip spray nozzle. Attached to the terminal end of the spray nozzle was a 1-m length of 9.5-mm (ID) polyethylene tubing, which was deemed a suitable length and diameter to reach the stomachs of the sampled catfish. The terminal end of the tubing was heated with a flame and rounded to facilitate inserting the tube through the esophagus into the stomach.

Fish selected for PGL sampling were held head down at an approximately $45^{\circ}$ angle, dorsal side up, by one member of the sampling team, while another member inserted the tubing through the esophagus into the stomach. Once the tube was in place, the pump was turned on, and the fish was held with its mouth over a fine-mesh aquarium net. Pulses of water were then directed into the stomach and allowed to flow back out, flushing the stomach contents into the net. During this process, the fish's abdomen was massaged to facilitate the flow of water and stomach contents. Once it appeared that no additional stomach contents were being flushed, the materials from the net were transferred to a plastic bag, sealed, labeled, and stored on ice.

Stomach tubes used in this study were 2-mmthick transparent, acrylic tubes of 13, 23, 36, 43, and $97 \mathrm{~mm}$ (ID). The tube ends were ground to a rounded, smooth edge with an electric rotary tool, and the largest diameter tube that would not injure the fish was selected for each individual. Fish selected for tube sampling were held head and dorsal side up by one member of the sampling team, while another inserted the wetted stomach tube. Water was then added to the stomach through the tube. Once water filled the stomach and was visible in the tube, the open tube end was capped, the fish was inverted three times, and the water and stomach contents were emptied through the tube into the same aquarium net as was used for the PGL procedure. This procedure was repeated until no additional stomach contents were collected (usually three times). Materials gathered in the net were stored in the same manner as the PGL samples.

All extracted diet materials and excised fish stomachs were returned to the laboratory, frozen, and subsequently thawed. The extracted stomach contents were blotted and weighed wet $( \pm 0.01 \mathrm{~g})$. Thawed fish stomachs were dissected, and any diet materials found were removed, blotted, and individually weighed $( \pm 0.01 \mathrm{~g})$. The relative weight of diet material was calculated as a percentage of the diet wet weight relative to the weight of the live fish. The effectiveness of each technique was determined by comparing the mass of stomach contents collected by each nonlethal procedure with that which remained in the stomach, expressed as a percent of the total contents by weight. Calculations of total and relative weight of diet material included fish with empty stomachs; diet recovered for each technique did not include those with empty stomachs. We compared effectiveness between techniques within each species by using one-way analysis of variance (ANOVA). Results were considered significant at $\alpha=0.05$.

\section{Results}

Mean length and weight were $541 \mathrm{~mm}(\mathrm{SE}=$ 13) and $1,928 \mathrm{~g}(\mathrm{SE}=162)$ for blue catfish, respectively, and $559 \mathrm{~mm}(\mathrm{SE}=22)$ and 2,739 $\mathrm{g}$ $(\mathrm{SE}=337)$ for flathead catfish (Table 1). All blue 
TABLE 1.-Fish sizes and results (mean \pm SE; range in parentheses) of pulsed gastric lavage (PGL) and stomach tube techniques for collecting diet samples from blue catfish and flathead catfish. Relative weight $=($ diet wet weight $) /($ live fish weight) $\times 100$.

\begin{tabular}{|c|c|c|}
\hline Variable & Blue catfish $(N=63)$ & Flathead catfish $(N=95)$ \\
\hline Total length (mm) & $541 \pm 13(383-800)$ & $559 \pm 22(190-1,090)$ \\
\hline Weight (g) & $1,928 \pm 162(500-6,810)$ & $2,739 \pm 337(54-14,800)$ \\
\hline Empty stomachs (\%) & 0 & 37.8 \\
\hline Total weight of diet material $(\mathrm{g})$ & $53.5 \pm 6.1(4.1-263.2)$ & $2.7 \pm 0.9(0-70.0)$ \\
\hline Relative weight of diet material (\%) & $2.7 \pm 0.3(0.6-19.6)$ & $0.3 \pm 0.1(0-10.1)$ \\
\hline Diet recovered by PGL $(\%)^{\mathrm{a}}$ & $95.6 \pm 1.4(74.6-100)$ & $96.0 \pm 3.7(0.9-100)$ \\
\hline Diet recovered by stomach tube $(\%)^{\mathrm{b}}$ & $14.6 \pm 3.1(0-75.7)$ & $86.9 \pm 5.6(0-100)$ \\
\hline Time required for PGL procedure $(\mathrm{s})^{\mathrm{c}}$ & $69 \pm 6(30-122)$ & \\
\hline Time required for stomach tube procedure $(\mathrm{s})^{\mathrm{d}}$ & $118 \pm 12(60-336)$ & \\
\hline
\end{tabular}

${ }^{a} N=32$ for blue catfish; $N=27$ for flathead catfish.

b $N=31$ for blue catfish; $N=33$ for flathead catfish.

${ }^{\mathrm{c}} N=20$.

${ }^{\mathrm{d}} N=26$.

catfish stomachs contained diet materials, but 35 (37.8\%) flathead catfish stomachs were empty. Mean total wet weight of diet material was 53.5 $\mathrm{g}(\mathrm{SE}=6.1)$ for blue catfish and only $2.7 \mathrm{~g}$ $(\mathrm{SE}=0.9)$ for flathead catfish. Mean relative wet weight of diet materials [(total weight of diet materials)/(total fish weight + total weight of diet materials $) \times 100$ ] for blue catfish was $2.7 \%$ (SE $=0.3), 0.3 \%(\mathrm{SE}=0.1)$ for flathead catfish (Table 1).

The relative effectiveness of the two techniques in sampling fish diet varied between species. Pulsed gastric lavage yielded a significantly greater percent recovery of diet materials than stomach tubes did for blue catfish $(F=579.37$; df $=1,61$; $P<0.001)$, but not for flathead catfish $(F=1.66$; df $=1,58 ; P=0.203$; Table 1$)$. Only seven dissected flathead catfish stomachs still contained material after the nonlethal procedure (two by PGL and five by stomach tube). A single PGL procedure could be completed in $58 \%$ of the time (mean $=69$ $\mathrm{s}, \mathrm{SE}=6 \mathrm{~s})$ required to perform the analogous stomach tube procedure $($ mean $=118 \mathrm{~s}, \mathrm{SE}=12 \mathrm{~s})$.

\section{Discussion}

Two factors may explain the observed effectiveness of each method-diet composition and internal morphology - both of which differed between the catfish species. Diets of the flathead catfish sampled were predominately small fish and aquatic macroinvertebrates (primarily crayfish), whereas all of the blue catfish sampled consumed diets that were primarily filamentous algae with an occasional snail (Gastropoda), Asian clam Corbicula fluminea, or small fish. The stomach tube was presumably unable to loosen the compacted mass of algae within the blue catfish stomach, and may have been more efficient if the diet had consisted of fish and invertebrates, like that of the flathead catfish.

One fish sampled by each technique had eaten a smaller catfish (one channel catfish I. punctatus and one unidentified madtom Noturus species) that had become lodged in the stomach by its pectoral spines; it is doubtful whether any nonlethal procedure could have removed them. A small rock remained in the stomach of another flathead catfish sampled by PGL. Items missed by the stomach tube procedure on flathead catfish were primarily crayfish (whole and parts), but one stomach contained an entire sunfish Lepomis species.

The other likely factor explaining the observed difference in the effectiveness of the two procedures on blue catfish is that the internal morphology of this species may differ from that of flathead catfish. During the process of stomach excision, we observed that the stomachs of blue catfish had a pronounced u-shape, a characteristic we did not see in flathead catfish stomachs. This curvature in the blue catfish stomach probablyly prevented extraction of a substantial portion of the contents through the stomach tube.

In addition to the variable and low effectiveness of stomach tubes, their use took more time, and extracted diet items were more damaged than those extracted by PGL (Table 1). We qualitatively observed that stomach tubes commonly crushed many of the diet items into smaller pieces, whereas PGL allowed the contents to remain intact as they were flushed from the stomach.

We were able to successfully perform the PGL procedure on flathead catfish as small as $203 \mathrm{~mm}$ and the stomach tube procedure on fish as small as $190 \mathrm{~mm}$. Smaller fish could probably be sam- 
pled with PGL; however, smaller-diameter tubing and a pump capable of a lower flow rate would be necessary to reduce stress and trauma on the fish. Strange and Kennedy (1981) devised a mechanism for flushing stomach contents from fish less than $100 \mathrm{~mm}$ long by utilizing a small Pasteur pipette and hand bulb; we suggest that this technique would also work well for small catfish, but it should first be evaluated.

We recommend that PGL be used in diet studies of blue catfish and flathead catfish where live fish release is desired. The effectiveness of PGL was significantly better for blue catfish but not for flathead catfish, the time required to perform each PGL procedure was substantially less than that of the stomach tube, and PGL did not damage the diet material.

\section{Acknowledgments}

We thank the biologists of Carolina Power and Light Company, Duke Power Company, North Carolina Museum of Natural Sciences, North Carolina Wildlife Resources Commission (NCWRC), South Carolina Department of Natural Resources, South Carolina Aquarium, U.S. Fish and Wildlife Service, and Georgia Power Company, who helped collect fish on the Pee Dee River. We also appreciate the assistance of Christian Waters, Keith Ashley, Tom Rachels, and Jason Farmer of the NCWRC on Sutton Lake and that of Edward Malindzak in the field and laboratory. Don Jackson, Dave Hewitt, Jim Rice, and Jason Vokoun provided constructive manuscript reviews. This research was funded by the North Carolina Wildlife Resources Commission through Federal Aid in Sport Fish Restoration funds (Project F-68).

\section{References}

Arterburn, J. E., D. J. Kirby, and C. R. Berry, Jr. 2002. A survey of angler attitudes and biologist opinions regarding trophy catfish and their management. Fisheries 27(5):10-21.

Crossman, E. J., and J. G. Hamilton. 1978. An apparatus for sampling gut contents of large, living fishes. Environmental Biology of Fishes 3:297-300.

Foster, J. R. 1977. Pulsed gastric lavage: an efficient method of removing the stomach contents of live fish. Progressive Fish-Culturist 39:166-169.

Fuller, P. L., L. G. Nico, and J. D. Williams. 1999. Nonindigenous fishes introduced into inland waters of the United States. American Fisheries Society, Special Publication 27, Bethesda, Maryland.

Hartleb, C. F., and J. R. Moring. 1995. An improved gastric lavage for removing stomach contents from live fish. Fisheries Research 24:261-265.

Irwin, E. R., W. A. Hubert, C. F. Rabeni, H. L. Schramm, Jr., and T. Coon, editors. 1999. Catfish 2000: proceedings of the international ictalurid symposium. American Fisheries Society, Symposium 24, Bethesda, Maryland.

Kamler, J. K., and K. L. Pope. 2001. Nonlethal methods of examining fish stomach contents. Reviews in Fisheries Science 9:1-11.

Light, R. W., P. H. Adler, and D. E. Arnold. 1983. Evaluation of gastric lavage for stomach analyses. North American Journal of Fisheries Management 3:8285.

Michaletz, P. H., and J. G. Dillard. 1999. A survey of catfish management in the United States and Canada. Fisheries 24(8):6-11.

Seaburg, K. G. 1957. A stomach sampler for live fish. Progressive Fish-Culturist 19:137-139.

Strange, C. D., and G. J. Kennedy. 1981. Stomach flushing of salmonids: a simple and effective technique for the removal of the stomach contents. Fisheries Management 12:9-15.

Van Den Avyle, M. J., and J. E. Roussel. 1980. Evaluation of a simple method for removing food items from live black bass. Progressive Fish-Culturist 42: 222-223.

White, H. C. 1930. Some observations of the eastern brook trout ( $S$. fontinalis) on Prince Edward Island. Transactions of the American Fisheries Society 60: 101-108. 